\title{
Arduous Learning or New Uncertainties? The Emergence of German Diplomacy in the Ukrainian Crisis*
}

\author{
Wolfgang Seibel \\ University of Konstanz
}

\begin{abstract}
'The Russia lobby in Germany: Berlin's foreign policy leadership boils down to "let's-talk-thisover" and "maybe-we-can-do-nothing".'

John Vinocur, The Wall Street Journal, 31 March 2014
\end{abstract}

'The deep desire for partnership with Russia has blindfolded German [foreign] policy.'

Marieluise Beck, spokesperson of the German Green Party for East European affairs, in Frankfurter Allgemeine Zeitung, 11 October 2014.

'What, then, will Germany choose? It will, I think, choose not to choose. (...) Sowohl-als-auch, or, in the immortal words of Yogi Berra, "if you see a fork in the road, take it!"'

Timothy Garton Ash, 1994

\section{A triple challenge}

None of the above statements is entirely justified. What they express, however, is misgivings about what has been termed in the lingua franca of classic diplomacy les incertitudes allemandes. The subject is German strategic foreign policy in the postCold War era, Germany's special relationship with Russia and the conduct of German diplomacy in the Ukrainian crisis since early 2014.

It remains to be seen whether 2014 will go down in history as the watershed year that marks the end of the postCold War era which began in 1989. What is certain, however, is that Germany played a crucial role in both of those historic moments. That role is connected with Germany's central geographic location, its close political and economic links with all other crucial players in the West

* am indebted to Lars Brozus, Tobias Bunde, Steffen Eckhard, Dirk Leuffen, Diana Panke, Gunter Hellmann and an anonymous reviewer of Global Policy for helpful comments on the draft version of this paper. I alone am responsible, however, for all remaining flaws and errors. and the East of Europe, the dominance that results from both positional centrality and the country's economic strength and, last but not least, Germany's legacy as an aggressive and disastrously failing European hegemon in the first half of the 20th century. At first glance, the circumstances differ substantially. In 1989, the fact that Germany was divided between the opposing blocs of the bipolar hegemony of the Cold War made national reunification both the trigger-event and the capstone of the stable and peaceful transition from communist rule and bloc-confrontation to what was meant to be an all-European order of freedom and democracy. In 2014, it was Germany's dominant role within the EU and its wellestablished political partnership with Russia that made German diplomacy the center-piece of western crisis management.

Some parallels between 1989 and 2014 are, however, striking. Ukraine is the only country in the former Soviet bloc where the rollback of democracy imposed by an authoritarian regime met stiff opposition from a nationwide civil movement. It was triggered when the then President Viktor Yanukovych radically changed course, suspended, in November 2013, negotiations with the EU on an association agreement and declared Ukraine's readiness to join the Russian-led Eurasian Customs Union. What became known as the Euro Majdan was the most vehement civil unrest in Europe since the demise of communism in 1989.

That parallel, however, had no impact on German public opinion. No 'solidarity with the Majdan' movement emerged in Germany, a country that takes pride in the history of the civil unrest that triggered the demise of communist rule in East Germany and beyond a quarter of a century ago. Instead, the Ukrainian events were framed in terms of EU vs Russia rivalry. What is more, within that biased frame, a relative majority of Germans declared in spring 2014 that they were in favor of a 'middle position' of Germany between the west and Russia in handling the Ukrainian crisis, and 61 per cent rejected enhanced North Atlantic Treaty Organization (NATO) engagement in Poland and the Baltic States. ${ }^{1}$ Prominent members of the 
Social Democratic and the Christian Democratic parties, now forming a Grand Coalition in Berlin, openly defended the Russian perspective and, thus, indirectly justified the Russian aggression against Ukraine. ${ }^{2}$ Similar statements were made by Peter Gauweiler, vice chairman of the Bavarian Christian Democrats (CSU) and by Armin Laschet, chairman of the influential Christian Democrats in North-RhineWestphalia. ${ }^{3}$ They were echoed in the German business world, most prominently by Eckhard Cordes, chairman of the 'Ost-Ausschuss der Deutschen Wirtschaft' (Committee on Eastern European Economic Relations) who in countless interviews underlined the importance of Russia for German business interests and was particularly outspoken against EU sanctions in reaction to the Russian annexation of Crimea. ${ }^{4}$ Matthias Platzeck who used to be prime minister of the state of Brandenburg (1998 2013) and was briefly chairman of the Social Democratic Party (SPD) (2005 2006) pleaded for the international recognition of the annexation of Crimea. ${ }^{5}$ In December 2014, dozens of former politicians and diplomats as well as artists and celebrities of various sorts including former Federal President Roman Herzog, former Chancellor Gerhard Schröder and Academy Award nominee movie director Wim Wenders - published an 'Appeal for Dialogue with Russia' in the weekly Die Zeit in which NATO expansion was made responsible for Russian anxieties while Russia's undeclared war against Ukraine remained unmentioned. ${ }^{6}$

German diplomacy in the Ukrainian crisis was therefore facing a triple challenge. The federal government had to readjust its own perceptions of, and overall strategy vis-à-vis, Russia. This had to be done in a political environment shaped by public opinion which was unsusceptible to solidarity with the civil unrest in Ukraine and rejected confrontational measures against Russia. And, last but not least, German diplomacy had to organize consensus and cohesion among the $28 \mathrm{EU}$ member states in response to the Russian aggression against Ukraine.

Put in theoretical terms, German diplomacy had to avoid misperceptions (cf. Jervis, 1976) and to adjust some of its principled and causal beliefs as far as Russia and Russia's strategic foreign policy was concerned. ${ }^{7}$ According to the two-level game logic that shapes the linkage between governmental strategy and decision making at the international level and acceptance and support by the domestic constituency (cf. Putnam, 1988), German diplomacy had to signal credibly its resolve to respond to the Russian aggression while avoiding the alienation of a domestic constituency reluctant to accept confrontational measures. Widening the 'win set' of feasible solutions that did justice to both requirements was the order of the day. The very same logic applied to Germany's role as a consensus broker within the EU. The requirement here was to strike a balance between the demands of Poland, Lithuania, Latvia and Estonia for harsh economic sanctions against Russia and the deploy- ment of additional NATO combat troops on their respective territories, on the one hand, and the reluctance of Italy, Hungary, the Czech Republic and Slovakia to support action that could expose them to Russian countermeasures in terms of oil and gas supply on the other.

The remainder of this article is devoted to the patterns and performance of the German response to those challenges. Based on an assessment of the legacies, mindsets and interests that shape strategic German foreign policy, the analysis focuses on how Germany's crisis management unfolded since the violent clashes in Ukraine in early 2014. A preliminary conclusion is that German foreign policy did adapt its principled beliefs as far as the German Russian relationship is concerned but did not manage to adapt decisively causal beliefs at the tactical level. This implies that while German foreign policy makers displayed remarkable skill in organizing the political consensus within both EU and NATO frictions persisted at the domestic and the international level. On the one hand, the Russian aggression against Ukraine galvanized the German efforts to redefine the country's role in NATO and to adjust both military spending and armament policy. On the other hand, German political elites as well as public opinion will remain a target zone for Russian efforts to exploit latent cleavages and fault lines as part of an adventurous experiment: purposeful destabilization as a geopolitical tool.

\section{The setting}

\section{Part 1: legacies, mindsets, and interests}

While President Viktor Yanukovych of Ukraine had dismantled most of the democratic achievements of the Orange Revolution of 2004/2005, his decision of 21 November 2013, not to sign a trade pact and a political association agreement with the EU triggered a wave of civil unrest that became known as the Euro Majdan, named after the Majdan Nezalezhnosti (Independence Square) in Kiev where the demonstrations against Yanukovych and his regime originated. Yanukovych ultimately agreed to reinstate the previously suppressed constitutional achievements of the Orange Revolution but fled the country on 21 February 2014, immediately after an agreement between his government and the Euro Majdan movement had been brokered under the auspices of four guaranteeing powers, namely France, Germany, Poland and Russia. ${ }^{8}$ He resurfaced after a couple of days in Southern Russia accusing the Majdan movement of a coup d'état that allegedly had made the agreement obsolete. Those accusations became part and parcel of Russian propaganda designed to justify what was portrayed as the protection of ethnic Russians in Ukraine and resulted in barely concealed military aggression against Ukraine, whose first and most significant 
step was the blunt annexation of Crimea completed in early March 2014. The second step was the establishment and military backing of so-called separatist forces in the Eastern provinces of Ukraine under the cover of camouflage and outright denial. Russia's insurgency in Eastern Ukraine caused a protracted civil-war-like conflict which, by fall 2014, had claimed some 3,600 human lives and left more than 8,700 wounded. ${ }^{9}$

Russia's strategic change of course towards military aggression for the sake of territorial gains and regional destabilization destroyed one of the main pillars of German foreign policy towards Russia known as 'partnership in modernization', based on the notion of regional peace and stability through mutual political and economic benefit. Accordingly, the Ukrainian crisis not only took the German political elite off guard which was the case in all the other capitals of western democracies but forced the German political class to redefine an entire segment of the country's strategic foreign policy.

The geopolitical consequences of the collapse of communism in 1989/90 and the dissolution of the Soviet Union in 1991 had remained a blind spot of German foreign policy, just as early diagnoses had predicted (Ash, 1994; Seibel, 1992). The linkage between democracy, not as a mere constitutional order but as the profound expression of the strength of civil society, on the one hand, and the demise of hegemony as a viable geopolitical concept on the other did not take root in the mindsets of German foreign policy makers. Although German politicians paid lip service to the notion of the peaceful revolution that overcame the communist regime of the German Democratic Republic, it was national reunification as such and its political administrative management that left the decisive footprint in the German collective memory (cf. Jarausch, 2013). Neither the force of civil society nor the miraculous peacefulness of the collapse of an entire geopolitical order were appropriately acknowledged, let alone Germany's new responsibility as a dominant power on the European continent. Significantly enough, 'Germany's second chance', as Fritz Stern had aptly characterized the consequences of 1989, was not truly grasped as such in the affected country.

The resulting mindset, however, nicely fitted the political and economic interests of Germany and its European neighbors. After all, for the first time in the country's history, a unified Germany was firmly embedded in multilateral international arrangements, first in NATO and then in what is today the EU. German leadership, let alone dominance, was not what, in 1989 and 1990, the rest of Europe was in need of. Moreover, since the days of the West German economic miracle (Wirtschaftswunder) the German political and business elites had deeply internalized the lesson that penetrating markets abroad was much more effective and much less risky a policy than conquering territories. What resulted from this was a mix- ture of self-adulating narratives and robust pursuit of economic interests. The narratives were devoted to Germany's history as an aggressive and militaristic power whose supposed present-day mission was to refrain from the use of military force for the sake of foreign policy goals (Maull, 1992). Hence Germany's limited role in NATO and the self-description of German foreign policy as being based on a 'culture of military restraint'. This, however, did not prevent German governments from shaping postCold War economic governance in Europe according to the German model, especially when the eurozone was in the making (James, 2012; Mazzucelli, 1995). Both the Maastricht criteria and the institutional strength of the Central European Bank, located in Frankfurt, were German brainchildren, and were imposed on Germany's fellow EU member states in spite of considerable reluctance, especially in France and Italy.

The common logic of a policy of military constraint and of tight integration of a future common European currency zone was that, in the early 1990s, it served the strategic interests of both Germany and its western allies. The downsizing of Germany's armed forces to less than 50 per cent of the combined West and East German troops was part of the Two-Plus-Four-Treaty as the founding act of German reunification. Integrating Germany in a European currency union had been the long-term goal of other European nations, France in particular, whose purpose was to eliminate the dominant Deutsche mark and to tame Germany's economic power.

It soon turned out, however, that what was meant as structures and mechanisms restraining the power and influence of a unified Germany paved the way for German 'cherry picking' and economic dominance. Germany only selectively and reluctantly participated in the military missions of both the United Nations (UN) and the EU. Germany's military budget remained well under NATO's target rate of 2 per cent of the GDP. At the same time, Germany not only became the structural hegemon within the eurozone (cf. Bulmer, 2014; Paterson, 2011) but also the world's most export-dependent economy. ${ }^{10}$ This implies that the country's economic prosperity and social stability depends on a stable international environment, as Germany is not able and not willing to provide for its own security. When it comes to security, Germany is a free rider at the expense of those who suffer from German dominance on both domestic and export markets. Facing this profound contradiction is the crucial challenge of present-day German foreign and security policy. The bitter irony is that the Ukrainian crisis could serve this purpose well.

\section{Part 2: Germany's special relationship with Russia}

Due to geographic proximity, economic interdependence and overlapping zones of regional interests Germany and 
Russia share a common history of rivalry and partnership. Prussia, Austria and Russia managed regional stability in Central and Eastern Europe from the mid-18th century on. They formed the victorious coalition against Napoleon's France of 181314 and the subsequent Holy Alliance as the core of the political order of the Congress of Vienna that not only secured peace until 1914 but also subdued civil unrest wherever it threatened the stability of their respective pre-constitutional autocratic orders. The bond between the ruling elites of those countries even survived the First World War and the Bolshevik Revolution of 1917, which became apparent in the Rapallo agreement of 1922 and the clandestine military cooperation of the two vanquished countries during the 1920s. The Hitler Stalin Pact of August 1939, brokered with enthusiasm by the conservative career diplomats of the Auswärtiges Amt (Watt, 1989, pp. 447 461; Miner, 1994; Snyder, 2011, pp. 119 154), would have been unthinkable without this particular history of partnership for mutual benefit.

An integral part of that partnership was hegemonic arrogance vis-à-vis the minor powers and nations. Poland was the most prominent and indicative example. From 1772 on, Poland was subsequently dismantled by Prussia, Austria and Russia. Prussia helped Russia to suppress the Polish uprising of 1830-31. And, again, it was in line with this particular trait of hegemonic partnership that Poland was divided and dismantled for the fourth time through the German Russian agreement of August 1939. The German assault on the Soviet Union of June 1941 interrupted that continuity but only temporarily so. The military aggression itself but even more so the horrendous human sacrifices of the Soviet Union during the war, largely due to the quasi-genocidal character of German warfare, only reinforced pro-Russian feelings in both East and West Germany after 1945, this time primarily in the left-of-center part of the political spectrum (and, needless to say, under communist rule in East Germany). A sentiment of moral guilt and the quest for enduring peace formed the psychological climate in which the West German Ostpolitik could emerge in the 1960s.

It was in this formative period that the traditional proRussian leanings of the conservative German elites and the progressive spirit of enduring peace and partnership with Russia on the political Left amalgamated. Active détente policy under the aegis of the West German Social Democrats from the 1960s on remained just as Russiacentered and elite-centered as traditional German entente policy vis-à-vis Russia, in Bismarck style. On the one hand, this was an expression of political realism since, in the bi-polar hegemonic order of the Cold War, the Kremlin was key to any substantial political progress in West East relationships. On the other hand, the Russia-centeredness and elite-centeredness of West German détente policy was unrealistic precisely because it not only neglected but rather repudiated the significance and impact of the various oppositional civil society movements that ultimately would lead to the demise of communist rule in Central and Eastern Europe. The Social Democrat Helmut Schmidt, West Germany's chancellor from 1974 to 1982, took pride in his personal friendship with Edvard Gierek, the Polish communist leader, but did not make any attempt to acknowledge, let alone support, the Solidarność movement as a legitimate political opposition. Egon Bahr, 19661969 head of the Policy Planning Staff in the West German Foreign Ministry under the then Foreign Minister Willy Brandt and to many, and justly so, the true intellectual architect of Social Democrat Chancellor Brandt's Ostpolitik, continued to reject the idea of 'destabilizing' the communist regimes in Central and Eastern Europe through supporting oppositional movements or dissidents as late as the second half of the 1980s (cf. Ash, 1993, pp. 312 319).

When 'destabilization' in fact did occur and communist regimes in Central and Eastern Europe collapsed almost overnight, German foreign policy nonetheless successfully dealt with the consequences. After all, Germany won 'the biggest prize', which was reunification, and the postCold War order was entirely compatible with the broad consensus on which a German Russian rapprochement was based. Germany became a determined supporter of integrating Russia in a common European security architecture. The NATO Russia Founding Act of 1997 is the related key document. Germany's close political linkages to Russia paralleled by close personal relationships of Chancellors Helmut Kohl (CDU, tenure 1982 1998) and Gerhard Schröder (SPD, tenure 1998 2005) to their respective Russian counterparts Boris Yeltsin (Russian President 1991 1999) and Vladimir Putin (Russian President 20002008 and 2012 present, Russian Prime Minister 19992000 and 2008 2012) culminated in the notion of a 'strategic partnership' whose core ingredient was supposed to be a 'partnership in modernization' (Modernisierungspartnerschaft). ${ }^{11} \mathrm{~A}$ significant footnote is that Schröder, once out of office in 2005, became chairman of the shareholders' committee of Nordstream, the firm building and running a gas pipeline through the Baltic Sea and owned by a consortium of Russian, German and Dutch energy companies with the state-owned Russian Gazprom as the majoritarian shareholder.

The notion and potential practice of a German Russian 'partnership in modernization' perfectly fitted the strategic German preferences as far as reduced military expenditure and enhanced export markets were concerned. Schröder's successor Angela Merkel did not alter that course despite sporadic critical remarks on the human rights situation in Russia. Germany's close and dense economic linkages with Russia, complemented by a dense web of consultation and cooperation mechanisms among which the regular meetings of the two respective governments, held once a year, were the crucial elements until 2013. 
The flipside is Germany's considerable dependence on Russian oil and gas supply. ${ }^{12}$ And it is indicative that, despite some minor frictions, the intensified repression and restriction of constitutional and human rights since the beginning of Vladimir Putin's second presidential term in 2012 remained largely unaddressed in the manifold formats of cooperation and consultation between the two countries. Moreover, Germany tended to neglect strategic interests of its Eastern neighbors for the sake of smooth and profitable cooperation with Russia. The Nordstream gas pipeline, while strengthening the economic and political ties between Germany and Russia, decoupled Poland and the Baltic States from a common energy supply. At the same time, Nordstream bolsters Germany's position as an energy distribution hub in western Europe. This supports Russia's policy of bi-lateral agreements with EU member states with the intention of weakening inner-EU solidarity. It also makes individual EU member states more vulnerable to Russian political pressure or straight blackmailing. All this was based, however, on the illusion that Russia was indeed the partner the Germans wanted.

\section{The Ukrainian crisis as an external shock and a 'new German foreign policy'}

Germany would undoubtedly have continued to conduct a 'partnership in modernization' policy vis-à-vis Russia provided that Vladimir Putin and the Russian leadership did not resort to open violence in response to the failure of their coup, which was the integration of Ukraine into the Russian-led Eurasian Customs Union announced in November 2013. It was clear from the very outset that Ukrainian President Yanukovych had, as Swedish Foreign Minister Carl Bildt put it at the time, 'bowed deeply to the Kremlin' under Russia's 'politics of brutal pressure'. ${ }^{13}$ Germany was taken off guard for a mere technical reason, since, after the federal elections of September 2013, the new government was still in the making. It was even more remarkable that the newly appointed Social Democratic Foreign Minister, FrankWalter Steinmeier, took the opportunity of his inauguration speech on 17 December 2013 to call it 'absolutely outrageous how Russia has exploited the dire economic situation in Ukraine' to make it drop the envisaged association agreement with the EU. Steinmeier, who was Schröder's chief of staff and subsequently Merkel's foreign minister already in her first cabinet of 2005 2009, had the reputation of being one of the most ardent proponents of a German Russian 'partnership in modernization'. ${ }^{14}$ It is hard to determine whether he wanted to get rid of those stereotypes or whether he was really frustrated by the continuous disappointments he had to sustain in his efforts to build a true entente cordial with Russia.
President Yanukovych was still in office and Russia had not yet embarked on a course of blunt though concealed military aggression against Ukraine involving the annexation of Crimea, when high-ranking German officials promulgated what became known as, or was exaggeratedly named a 'new German foreign policy'. At the opening of the 50th Munich Security Conference in late January 2014, the President of the Federal Republic of Germany Joachim Gauck, Steinmeier and the newly appointed minister of defense, Ursula von der Leyen, underlined in various nuances that Germany, in accordance with the country's political and economic strength and importance, was determined to assume a wider range of international responsibilities, including military missions under the auspices of the UN, EU and NATO. ${ }^{15}$ At that particular moment probably none of them thought that Germany's response to the Ukrainian crisis could become the litmus test for the seriousness of those announcements. Earlier situations had been different. In spring 2011 Germany, as a temporary member of the UN Security Council, was isolated among its western allies in siding with Russia and China in an abstention vote on the erection of a no-fly zone over Libya designed to protect the citizens of Benghazi against a massacre literally announced by Colonel Gaddafi. And during the protracted Syrian crisis Germany had also remained on the sidelines. But in the management of the Ukrainian crisis it was propelled onto center stage.

However, this role was not the outcome of the ambitious statements made at the Munich Security Conference of January 2014 but the consequence of Germany's dominant position within the EU and its close ties to the states immediately affected Russia, Ukraine, Poland, and the Baltic States. German diplomacy just found itself in a situation where active crisis management was unavoidable. Its relative success, however, was dependent on a series of factors of uncertain predictability: one was a change of mindsets as far as German Russian relationship was concerned. A second requirement was the mobilization of domestic support for what necessarily would be a more assertive policy vis-à-vis Russia. And a third component was Germany's capacity to mediate among diverging interests and policy options within the EU. The resulting diplomatic strategy had to be played out in two institutional dimensions, EU and NATO, while the crucial tactical challenge was to develop and to display determination and credibility in a protracted conflict in which not only the political fate of Ukraine and the Ukrainians was at stake but regional stability and peace in Eastern Europe as well.

In response to these requirements, the German diplomatic strategy unfolded in several phases. A pre-phase was the period before the military annexation of Crimea by camouflaged Russian forces in late February and early March 2014. It resulted in the decisions taken by the 
European Council on 6 March 2014, whose crucial part was a sanction plan to be implemented in accordance with Russia's compliance or noncompliance with the western efforts to reach a diplomatic solution to the conflict. A second phase stretched from early March to mid-May 2014 when a so-called contact group was established under the auspices of the Organization for Security and Cooperation in Europe (OSCE) in which Russia and Ukraine were supposed to participate. A third phase lasted from mid-May to 17 July when a Malaysian airplane was downed over East Ukrainian territory controlled by pro-Russian insurgents. A fourth phase stretched from 17 July to 5 September 2014, when a ceasefire between Ukraine and the pro-Russian separatists was agreed on in the Belarus capital Minsk, followed by a fifth phase in which the Minsk accord was supposed to be implemented. Across those phases German diplomacy faced the double challenge of changing its strategic disposition vis-à-vis Russia under serious domestic restrictions determined by public opinion and economic interests and of assuming the unfamiliar role of the indispensable crisis manager. It nonetheless gained momentum and coherence. Yet fault lines remained, and whether or not the current crisis will result in successful containment of the Russian aggression, in enduring instability or, even worse, in a Ukrainian civil war, remains an open question for the time being.

\section{Adjusting principled beliefs}

Russia's annexation of Crimea and the subsequent military aggression in Eastern Ukraine made obsolete what until then was virtually the strategic fundament of German policy towards Russia, namely the 'partnership in modernization'. It was taken for granted a principled belief that it was in Russia's own interest to modernize its primary industry-based economy, to consolidate rule of law structures and to guarantee civil liberties. Just like the US's Obama-administration under the auspices of its 'reset' policy, the German Federal Government was driven by sincere confidence that, according to a rational definition of Russian interests in both the domestic and the international realm enduring partnership with the west was without reasonable alternative. And just like the US government the German counterpart had a hard time abandoning related illusions.

Steinmeier, in his above mentioned inauguration speech, clearly expressed his frustration when he called it 'absolutely outrageous how Russia has exploited the dire economic situation in Ukraine' to bring the country to cancel the envisaged association agreement with the EU. Steinmeier also insisted that 'it is Moscow's obligation to define and to explain common interests that potentially exist between Russia and Europe'. ${ }^{16}$ However, when Steinmeier went to Moscow, at the height of the Majdan protests and its brutal repression by the Yanukovych regime backed by the Russian government, he refrained from any specific comment in his public utterances on Moscow's involvement. Instead, Steinmeier reiterated that Russia 'is needed for the solution of virtually all crises and conflicts of our time' and he pleaded for a substantial expansion of the 'constructive cooperation [between Germany and Russia] in as many areas as possible', for example in the form of 'projects in the areas of rule of law, health, strengthening municipal self-administration or the expansion of cooperation in education, science and research'. ${ }^{17}$ This was still vintage 'partnership in modernization' and it was an arduous task to convert it into operational crisis management.

It was on Steinmeier's initiative that the Franco German Polish 'Weimar Triangle' was reanimated. On 20 and 21 February, French Foreign Minister Laurent Fabius, his Polish colleague Radosław Sikorski, Steinmeier and Russian diplomat Vladimir Lukin brokered an agreement between President Viktor Yanukovych of Ukraine and representatives of the Majdan. Its main elements were the restoration of the constitutional rights abolished by the Yanukovych regime since 2010, further constitutional reforms, presidential elections in the year of 2014 and an independent investigation into the violence during the recent protests and their suppression. Again, German diplomats and politicians invested much hope in the constructive support of the agreement by Russia. This included repeated but erroneous statements that, after all, Russia had 'signed' the agreement of 21 February 2014 which, however, was not the case. ${ }^{18}$ It was an indicative sign of wishful thinking. Not only had Russia not signed the Kiev agreement of 21 February 2014 Russia's envoy Lukin declared that such a step would exceed his competences but instead gave asylum to the Ukrainian President Yanukovych once he had deserted his own country, and from that moment on treated the interim government in Kiev as illegitimate. It became apparent that Russia intended to destabilize Ukraine altogether.

It was only after the annexation of Crimea completed in early March 2014, however, that the German government substantially changed course. Tensions between the Federal Foreign Ministry and the Chancellery became visible when Steinmeier, on 2 March, still pleaded against excluding Russia from the G8 round although that step had already been approved by the governments of the US, the UK and France. ${ }^{19}$ Later that day, however, it was announced that the upcoming G8 summit, scheduled to be held in June in Sotchi at the Russian Black Sea coast, would be suspended. Chancellor Merkel obviously had held sway in the matter.

However, the annexation of Crimea and the use of military force by which it was completed mark the turning point beyond which the notion of a 'partnership in 
modernization' disappeared from German foreign policy language. Remaining divergences between the Chancellery and the Federal Foreign Ministry lost significance and German diplomacy was crucially instrumental in forging the decision of the European Council of 6 March 2014 that entailed a three phase system of economic sanctions on Russia while Merkel and Steinmeier unanimously condemned the annexation of Crimea as an act of unacceptable violation of international law. In the context of the Weimar Triangle, Steinmeier and his fellow foreign ministers Fabius of France and Sikorski of Poland affirmed the determination of those three countries to 'support taking new strong action' in case Russia should continue to pursue 'a policy that divides and splits Ukraine'. ${ }^{20}$ Remarkably enough, Steinmeier became very outspoken in warning corporate Germany not to sustain the hope for a return to 'business as usual' anytime soon. ${ }^{21}$ No doubt, Steinmeier's learning curve had been particularly steep. ${ }^{22}$ The Federal Foreign Office's Division of Strategic Planning (Planungsstab) made its own efforts to disseminate the foreign minister's new perspective on Russia. $^{23}$

\section{Adjusting causal beliefs}

While the Federal Government's principled beliefs were thus changing, the causal beliefs were not. Causal beliefs, according to Goldstein and Keohane (1993), are operational ideas about the best fit of cause and effect in foreign policy. Sanctions against Russia had been anathema to the Federal Government and the German political class in general until the annexation of Crimea and the same was true for a stronger presence of NATO in Eastern Europe through the deployment of combat troops. Berlin's mantra was to 'keep the communication channels open' and to talk with the Russians rather than to exert pressure on them. ${ }^{24}$ The causal belief behind this was that stepping up pressure on Russia would escalate the conflict. The learning requirement was to acknowledge that, facing a Russia determined to escalate anyway, the opposite was true. German diplomacy had a hard time to learn that lesson.

Chancellor Merkel attempted to broker a compromise between two requirements. One was doing justice to the quest of the US, Poland and the Baltic States for determined reactions to the Russian annexation of Crimea. The other was making concessions to the more than cautious domestic climate in Germany, to the reservations of both her coalition partner, the Social Democrats, and the German business world both were against sanctions that could affect the cooperative character of the German Russian relationship and, last but not least, Germany's economic interests. The three phase sanction system established by the European Council of 6 March 2014, was precisely that type of compromise. Phase one of those sanctions envisaged the suspension of bilateral talks with Russia including the cancellation of the G8 summit scheduled for June 2014. Phase two included travel bans, asset freezes and the cancellation of the EU Russia summit. Phase three envisaged 'additional and far-reaching consequences for relations in a broad range of economic areas between the EU and its member states, on the one hand, and the Russian Federation, on the other hand'. ${ }^{25}$

The decisions of the European Council of 6 March 2014, laid the groundwork of what in the perception of the German Federal Government was a pattern of negative and positive incentives for Russia to refrain from further aggression against Ukraine or further attempts at destabilization in general. Nonetheless, the Federal Government and representatives of the coalition partners in Berlin turned out to be ill-prepared for the skillful conduct of coercive diplomacy. Government officials sent mixed messages as far as the implementation of the EU sanction plan was concerned. While both Chancellor Merkel and Foreign Minister Steinmeier confirmed Germany's commitment to further sanctions in case of continued Russian noncompliance, Minister of Finance Wolfgang Schäuble said at the G20 Finance Ministers' and Central Bank Governors' Meeting in April 2014 it 'would make no sense' to talk about new sanctions against Russia for the time being. ${ }^{26}$ The prevailing belief, especially among Social Democrats, was that productive talks with Russia and sanctions were mutually exclusive.

Both Merkel and Steinmeier made concessions to these dispositions. In an interview of 20 April 2014 with the weekly Bild am Sonntag, a tabloid paper with high circulation, Steinmeier argued that an intensified, as he put it, 'sanction debate' could contribute to the aggravation (Zuspitzung) of the Ukrainian crisis. ${ }^{27}$ Merkel, on the occasion of her meeting with Putin at the 70th anniversary of the Allied landing in Normandy in Deauville, France, said that currently the issue was 'not the threat of sanctions but the quest for solutions through talks'. ${ }^{28}$

Those utterances not only unnecessarily exposed fault lines within the EU, as far as the implementation of the decisions of the European Council of 6 March 2014, was concerned, but also implied a misleading and thus counterproductive interpretation of the nature of coercive diplomacy in general. Juxtaposing 'sanctions' and 'escalation' basically meant undermining the effectiveness of the very mechanisms of a political solution' of the Ukrainian crisis which German diplomacy was aiming at. Casting doubt on the determination to implement the EU sanction plan could only encourage Russia to promote the very escalation of the conflict with Ukraine abjured by German foreign policy makers. Conversely, to describe as 'escalation' what was still a relatively modest countermeasure in response to the Russian annexation of Crimea and Russia's continued efforts to destabilize Ukraine altogether came close to Moscow's own rhetoric. It is hard 
to determine whether it was a tactical error or just a blunder that repeatedly made German foreign policy makers describe even Ukrainian defense measures as a risk of 'escalation'. ${ }^{29}$ These ambiguities did not remain unnoticed among outside observers. ${ }^{30}$

A particularly critical aspect of those ambiguities affected the consequences of the Russian aggression against Ukraine for the NATO. Germany's insufficient military spending and the resulting combination of cherry picking and free riding when it comes to the country's NATO obligations had been characterized as NATO's 'most significant problem' ${ }^{31}$ well before the outbreak of the Ukrainian crisis. Russia's aggression against Ukraine made obvious the vulnerability of NATO's Northeastern flank given the exposure of Estonia, Latvia and Lithuania states with considerable minorities of ethnic Russians and Poland. And it made apparent the untenability of Germany's reluctance to underpin the lip services paid to NATO in general and Article 5 of the NATO Treaty in particular with real action.

Defense Minister Ursula von der Leyen, a Christian Democrat, was necessarily most susceptible to the critical debates on the issue within NATO and made related public remarks as early as March 2014. ${ }^{32}$ Her initiative, however, immediately revealed the lack of consensus within the governing Grand Coalition. Vice Chancellor Sigmar Gabriel, chairman of the Social Democratic Party, hastened to rebuke the defense minister with the blunt statement that strengthening NATO in Eastern Europe was not on the agenda. ${ }^{33}$ Even more revealing was Gabriel's language: he said that the defense minister had created the impression that 'the next step of military escalation' was imminent. Military means according to Gabriel, were unnecessary for demonstrating the commitment to NATO. What was imperative, he continued, was 'a different way, which is the way of negotiations. $^{34}$

By characterizing the strengthening of NATO in Poland and the Baltic States vs negotiations as opposing options Gabriel in turn misinterpreted the nature of credible signaling in international relations. It should have been clear to an accomplished politician like him that nonnegotiated concessions do not yield any benefit in return in other words, that no Russian concessions could be expected as soon as NATO's concessions were presented to Russia upfront on a silver platter. ${ }^{35}$ Moreover, those statements weakened the solidarity with Poland and the Baltic States. They entailed a barely concealed arrogance since the German Vice-Chancellor implicitly pretended to have a better judgment on the security requirements of Poland and the Baltic States than these NATO member states themselves. It was therefore with concerns and irritation that the tensions and contradictions within the German government were realized among Germany's NATO allies. $^{36}$
While Defence Minister von der Leyen probably had had the intention of preparing German public opinion for the consequences of the intense debates within the inner circles of NATO about appropriate responses to the Russian annexation of Crimea as they had been reported in a memo by Germany's ambassador to NATO, Martin Erdmann, in the second half of March $2014^{37}$ the tactical purpose of Vice Chancellor Gabriel's critique was probably to make those consequences compatible with the pacifist sentiments within his Social Democratic Party. This, however, did not alter the fact that Foreign Minister Steinmeier's efforts to reanimate the Weimar Triangle and, thus, the close cooperation with Poland was quite at odds with the Social Democrats' reluctance to strengthen NATO in Poland and the Baltic States. ${ }^{38}$ Polish President Komorowski made related concerns public when, in May 2014, he asked for a more determined stance by Germany vis-à-vis Russia. Komorowski spoke of a 'suspicion that some politicians in Germany are conducting foreign policy in a way that is hard to accept for Poland'. ${ }^{39}$

Germany's particular obligations towards Poland, buttressed by warm personal relationships of Merkel and Steinmeier with their respective Polish counterparts Donald Tusk and Radosław Sikorski, together with the unmistakable expectations for a stronger German commitment within NATO, resulted in a compromise consisting of three elements: Germany pledged to enhance its contingent in the headquarters of the Multinational Corps North-East in Szczecin, Poland, to provide the flagship for the NATO flotilla in the Baltic Sea and to resume earlier as planned 'air policing' surveillance flights over Lithuania, Latvia and Estonia. ${ }^{40}$ The deployment of regular NATO ground troops, however, was taken off the agenda. What is more, Steinmeier hastened to exclude 'categorically' future NATO membership of Ukraine. ${ }^{41}$

Steinmeier's explicit statement, repeated at various occasions even when the military threat exerted by Russia was more than evident, ${ }^{42}$ demonstrated one more time both the nature of the inner-German compromise after all, domestically his remark primarily addressed a German public rejecting stronger NATO presence in Eastern Europe and the inclination of German diplomacy to make nonnegotiated and thus counterproductive concessions to Russia. This was especially so since the 'categorical' exclusion of future NATO membership of Ukraine was pronounced immediately prior to a meeting of NATO Ministers of Foreign Affairs held on 1 April 2014. Steinmeier abandoned what had been the official rhetoric of the German Federal Government with respect to NATO enlargement so far, namely that a Russian veto in enlargement affairs was unacceptable. The German foreign minister would have had more than one reason to use precisely that formula under the given circumstances. The fact that he did not do it was again indicative of 
what in the eyes of outside observers could easily appear as Germany's ambiguous commitment to NATO.

In sum, however, the compromise on NATO's reaction to the Russian aggression against Ukraine sealed at the meeting of NATO ministers of foreign affairs of April 12 2014, was a substantial contribution to widening the 'winset' the set of acceptable solutions of German diplomacy in the Ukrainian crisis. It combined what was acceptable to domestic public opinion with what was required as a minimum level of commitment to the solidarity with Poland, the Baltic States and, indirectly, Ukraine within the framework of NATO. That compromise laid the groundwork for a robust German position in the internal debates and negotiations in preparation of the NATO summit in Wales on 45 September 2014. At the Wales summit the German proposal, with slight adjustments, prevailed over Poland's and Baltic States' demand for substantial enhancement of NATO capacity on their respective territories. Flanked by visits of Chancellor Merkel to Latvia and Ukraine in August 2014, Germany insisted on keeping the NATO Russia Founding Act of 1997 intact, which excluded the 'permanent stationing of substantial combat forces' in future Central and Eastern European NATO member states regardless of the fact that Russia, through its aggression against Ukraine, was in flagrant breach of those agreements anyway. Moreover, the Founding Act had referred to 'the current and foreseeable security environment' that meanwhile had been altered dramatically and unilaterally by Russia. As a compensation, the NATO Wales summit announced a 'Readiness Action Plan' whose core is a substantial enhancement of military infrastructure in Poland and the Baltic States combined with a 'continuous presence and activity in the air, on land and at sea in the eastern part of the alliance, on a rotational basis' and a 'spearhead unit within the NATO Response Force' including 'several thousand land troops ready to deploy within a few days'. ${ }^{43}$

\section{Making diplomacy work: productive and counterproductive efforts}

When President Viktor Yanukovych of Ukraine was still in office, Germany started active crisis management in terms of shuttle diplomacy and back-channel brokerage. Initially, the reanimation of the Weimar Triangle (with a reluctant France though ${ }^{44}$ ) was the chosen format. Both French Foreign Minister Fabius and his German counterpart Steinmeier then came up with the idea of establishing a 'contact group', known from other crisis hot spots as an appropriate tool of mediation. Steinmeier soon suggested the OSCE as a framework. ${ }^{45}$ Russian President Putin agreed to the proposal in a telephone conversation with Chancellor Merkel on 2 March 2014. ${ }^{46}$

When the US, Russia, Ukraine and the EU, on 17 April 2014, reached an agreement in Geneva through which the conflicting parties affirmed their willingness to refrain from 'violence, intimidation or provocative actions' and pledged that all 'illegal armed groups will be disarmed' an OSCE Special Monitoring Mission was assigned a leading role in assisting Ukrainian authorities and local communities in the implementation of the agreement. A former German career diplomat, Wolfgang Ischinger, became the 'Representative of the OSCE Chairperson-inOffice for National Dialogue Roundtables in Ukraine' (a function assumed by the Turkish diplomat Ertugrul Apakan) and thus a crucial figure in what was meant to be a peace process for Ukraine. Ischinger had been a member of two similar 'contact groups' tasked with the settlement of the conflicts on the Balkans in the 1990s. His broad experience and close linkages to numerous Russian career diplomats, including Russian Foreign Minister Sergey Lavrov, as well as the fact that, initially at least, he was an outspoken critic of sanctions on Russia, ${ }^{47}$ should have made him a well-accepted interlocutor on the Russian side.

It soon became apparent, however, that Russia had no intention of implementing the Geneva Accord of 17 April 2014. On the contrary, Russia started to arm and to equip pro-Russian insurgents in the cities and regions of Lugansk, Sloviansk and Donetsk. According to all evidence, this was designed to destabilize Ukraine to a degree that would make the presidential elections scheduled for 25 May 2014, unfeasible. In early May 2014, Russian Foreign Minister Lavrov, referring to the ongoing violence in Eastern Ukraine, declared it 'useless' to organize such elections. ${ }^{48}$ In response to 'the continued efforts by separatists backed by Russia to destabilize eastern Ukraine' and to the absence of any 'concrete actions [of Russia] in support of the Geneva Accord' the group of G7, on 26 April 2014, announced in a joint statement that it would 'move swiftly to impose additional sanctions on Russia'. ${ }^{49}$ While the explicit purpose of the new sanctions was, according to the G7 statement, 'to ensure a peaceful and stable environment for the May 25 presidential election', German Foreign Minister Steinmeier had previously declared his reservations against new sanctions on Russia. ${ }^{50}$ It is unclear, given Germany's approval of the G7 decision of 26 April, how the divergent opinions within the German Federal Government were settled.

One might assume that the abduction of a group of observers of the OSCE, among them several Germans, by pro-Russian insurgents in Eastern Ukraine on 25 April 2014, was a tipping point beyond which Steinmeier would abandon his resistance against further sanctions on Russia. As a matter of fact, Steinmeier made extraordinary efforts to free the OSCE hostages, using his excellent personal links to Lavrov. When the hostages were finally freed eight days later, however, Steinmeier expressed enthusiastically his gratitude to the Russian government, ${ }^{51}$ 
which again revealed a certain weakness in judgment and diplomatic skill. Instead of expressing so warmly his gratefulness to a Russian government ultimately responsible for the circumstances that had made the abduction of the OSCE observers possible it would have been wise to pinpoint the obvious leverage exerted by the Russian government over the insurgents in Eastern Ukraine.

On 12 May 2014, Chancellor Angela Merkel traveled to Washington DC where, in a meeting stretching over four hours, she conferred with President Obama on the Ukrainian crisis. ${ }^{52}$ Given the mixed messages to be heard from German government circles about the policy vis-àvis Russia Merkel confirmed the determination of her government to implement to the full degree, if necessary, the three-phase sanction plan adopted by the European Council on 6 March 2014. In the meantime, Ischinger, in his capacity as de facto chairman of the OSCE contact group, made it clear in a series of interviews that any hope for productive talks with the proRussian insurgents in Eastern Ukraine would be in vain. The so-called 'separatists', Ischinger said, would represent nobody and they not only were not able but also not willing to negotiate. ${ }^{53}$

The presidential elections in Ukraine were held surprisingly smoothly on 25 May 2014, and candidate Petro Poroshenko won outright with a 55 per cent majority. Subsequently, the new Ukrainian government decisively intensified the military efforts to reestablish jurisdiction over the eastern Ukrainian regions of Lugansk, Sloviansk and Donetsk, meanwhile controlled by pro-Russian insurgents. In response, Russia multiplied pleas for a cessation of hostilities. Under the pressure of the EU read Germany President Poroshenko, on 20 June 2014, unilaterally declared a ceasefire. ${ }^{54}$ When a new meeting of the EU chiefs of government and heads of state, scheduled for 27 June 2014, was approaching it was evident that Russia had done nothing to honor the unilateral ceasefire pronounced by Ukraine, and that was precisely what the EU summit declared. ${ }^{55}$ Again, however, it was due to decisive German influence that no further sanctions on Russia were declared at the summit itself. Instead, a deadline was announced that granted Russia three more days 'to actively use its influence over the illegally armed groups and to stop the flow of weapons and militants across the border [between Russia and Ukraine], in order to achieve rapid and tangible results in de-escalation'. In referring to the decisions of 6 March 2014, that entailed the three-phase sanction plan, the European Council declared that on 30 June 2014, it would 'assess the situation and, should it be required, adopt necessary decisions' and underlined 'its commitment to reconvene at any time for further significant restrictive measures'. ${ }^{56}$

Clear and determined as these decisions were actually the most determined action taken by the European Council since its meeting of 6 March 2014 their imple- mentation was effectively undermined by the German government. Of the requirements formulated by the European Council in its statement of 27 June 2014, only one the release of OSCE hostages again taken by proRussian insurgents was fulfilled by 29 June. Otherwise the decision of the Council remained without Russian response that should have included an agreement on an OSCE monitored verification mechanism for the ceasefire, the effective control of the Russian Ukrainian border, the return to the Ukrainian authorities of three itemized border checkpoints and the launch of substantial negotiations on the implementation of the peace plan meanwhile submitted by Ukrainian President Poroshenko. So 'further significant restrictive measures' further sanctions on Russia should have followed in accordance with the Council's decisions of 27 June. The chairman of the Foreign Relations Committee of the German Bundestag, Norbert Röttgen, a Christian Democrat, predicted, in a radio interview of 1 July 2014 that precisely this would happen the very same day. After all, Röttgen said, the credibility of the EU was at a stake. ${ }^{57}$

However, foreign minister Steinmeier had meanwhile praised the 'important role of Russia' in achieving the release of the OSCE hostages. ${ }^{58}$ Again, Steinmeier failed to underline that this demonstrated one more time Russia's leverage over the insurgents in Eastern Ukraine. He also failed to ask, in accordance with the EU decisions of 27 June, for Russia to use its influence to make the insurgents comply with the requirements of, at least, an effective ceasefire and an OSCE monitored verification mechanism. What is more, Chancellor Merkel and French President Hollande, in a telephone conversation of 29 June 2014 with Russian President Putin, had agreed to support Putin's demand to extend the ceasefire unilaterally declared by Ukraine (and constantly violated by Russian-supported insurgents). ${ }^{59}$ Although Merkel and Hollande once again asked for the implementation of Poroshenko's peace plan the immediate effect of their agreement with Putin was to suspend the decisions of the European Council of 27 June 2014. So the very credibility of the EU, which for Röttgen was at stake, had already been severely damaged when he, still in good faith, predicted in his Deutschlandfunk interview of 1 July 2014, that new EU sanctions were imminent.

What resulted from the Franco German intervention was a meeting of the foreign ministers of Germany, France, Russia and Ukraine in Berlin held 2 July 2014. The foreign ministers issued a 'joint declaration' through which they 'strongly reconfirm[ed] their commitment to sustainable peace and stability in Ukraine' and stressed 'the necessity of a sustainable ceasefire'. These vague formulas were completed with the announcement of another meeting of the OSCE contact group 'no later than July $5^{\text {th }}$ with the goal of reaching an unconditional and mutually agreed sustainable ceasefire'.60 
In essence, the EU, under the decisive influence of France and Germany, increased the pressure on Ukraine while decreasing the pressure on Russia. The 'joint declaration' of 2 July 2014, de facto revoked the decisions of the European Council of 27 June and left it to the discretion of Russia to comply or not to comply with the requirements of an 'unconditional and mutually agreed sustainable ceasefire', monitored by the OSCE. Without further EU sanctions in the offing, the outcome was predictable. Not even the Russian Ukrainian talks, scheduled to start 5 July 2014, materialized, let alone the 'close collaboration between Russian and Ukrainian border authorities' mentioned in the 'joint declaration'.

German media comments on the alleged extension of the ceasefire in Ukraine and the meeting of the four foreign ministers of 2 July 2014, were again indicative. By mere chance, the meeting coincided with the farewell visit to Berlin of NATO Secretary General Anders Fogh Rasmussen. His appearance was portrayed in some media as the opposite of the alleged peace talks between the foreign ministers of Ukraine, Russia, France and Germany. Politicians of the governing Grand Coalition were quoted as saying that they were afraid of Rasmussen using the common press conference with Merkel to spoil Berlin's 'course of de-escalation' as far as Ukraine was concerned. The crucial issue of the day, according to these sources, was 'definitely no sanctions'. ${ }^{61}$ It was just another sign of the deeply engrained misperception of how sanctions and the potential for de-escalation were causally interlinked.

German wishful thinking, clinging to the vague idea of an alleged ceasefire, had no remedy in store against the continued Russian aggression in Eastern Ukraine. What is more, it virtually made the Ukrainian government responsible for any further escalation. This was precisely what the Federal Government's representative for Russian and East European affairs, Gernot Erler, expressed when, in an interview with Neue Osnabrücker Zeitung of 2 August 2014, he pointed to the 'very strong pressure' under which Putin found himself in the attempt not to let down the Russian-speaking people in Eastern Ukraine, whom he had taken, as Erler put it, 'under his protection'. 'When the separatists face military defeat, a direct intervention of Russia across the border [between Russia and Ukraine] cannot be excluded.' That sounded much more like an admonition addressed to the Ukrainian government than a warning addressed to Russia.

\section{Finally a 'game changer'? The downing of $\mathrm{MH} 17$}

The downing of the Malaysian civil airplane MH17 on 17 July 2014, was a decisive turning point in the German efforts to reach a diplomatic solution in the Ukrainian crisis. The death of 298 innocent civilians in a plane that, according to all evidence, had been shot down over East- ern Ukrainian territory controlled by pro-Russian insurgents was an eye-opener as far as the consequences of the ongoing violence in Eastern Ukraine was concerned. Its impact on public opinion in almost every country outside Russia was aggravated by the behavior of the proRussian insurgents at the crash site and its vicinity. An independent investigation into the causes and even an appropriate treatment of the victims was made impossible by gunmen, many of whom were apparently drunk and did not refrain from pillaging the corpses. The incident thus not only made it evident that the insurgency supported by Russia had created a situation in Eastern Ukraine in which violence was rampant and virtually unlimited but also that large contingents of the so-called separatists were just ruthless criminals.

For the first time the German government openly supported sectoral economic sanctions on Russia in accordance with phase three of the sanction system agreed by the European Council on 6 March 2014. Vice Chancellor Gabriel asked for the 'disarmament of the separatists' in Eastern Ukraine. ${ }^{62}$ Yet Foreign Minister Steinmeier continued to emphasize the flipside of sanctions on Russia and the detrimental effects on the German economy. Anger and disgust, Steinmeier said in an interview with the Frankfurter Allgemeine Zeitung referring to the death of the passengers of Malaysian Airlines flight MH17, 'cannot be the last word in foreign policy'. ${ }^{63}$ Steinmeier also emphasized the necessity of 'balanced sanctions' whose negative repercussions would have to be evenly shared by the EU member states. And, finally, talks and negotiations with Russia would remain indispensable, Steinmeier said. Again, these truisms were not designed to increase diplomatic pressure on Russia.

In the wake of the downing of $\mathrm{MH} 17$ and the subsequent efforts of the EU to decide upon further sanctions, Russia did not waste time in achieving a fait accompli and further destabilization in Eastern Ukraine. From the end of July 2014 on, western intelligence services reported a massive influx of troops and weapons from Russia into insurgent-controlled areas in Eastern Ukraine. This prompted Chancellor Merkel to ask President Putin in a telephone call of 16 August 2014, to stop the 'stream of armament, military advisers and armed personnel over the [Russian Ukrainian] border'. ${ }^{64}$ In the second half of August 2014, however, the pro-Russian insurgents, meanwhile reinforced by Russian military personnel and heavy weaponry, launched an offensive against Ukrainian regular forces and soon made substantial territorial gains. Parallel to this offensive, Russia, with great propaganda efforts, organized a convoy of several hundred trucks, declared as 'humanitarian aid', an initiative whose obvious purpose was not only to organize the proverbial offer Ukraine could not afford to refuse but to distract international attention from the simultaneous military offensive that was the closest thing to 
open Russian military aggression against Ukraine so far. When the fall of the Ukrainian city of Mariupol on the Black Sea coast and a Russian attempt to establish a land corridor between Russia and the annexed Crimea seemed to be imminent, Steinmeier pronounced one of his rare direct alerts addressed to the Russian government in saying that such a step would be just as much a violation of international law and subject to condemnation as the annexation of Crimea' ${ }^{65}$

Nonetheless, August and September 2014 marked a new period of active German brokerage within the EU and NATO for coherence and determination vis-à-vis Russia in the Ukrainian crisis. An intense process of backchannel negotiations and shuttle diplomacy, mainly initiated and upheld by German government officials, including Merkel herself and Steinmeier, focused on three crucial areas. One was the coordination of further steps to a decisively elevated level of economic sanctions on Russia, now affecting entire sectors of the Russian economy. A second issue was the preparation of the long awaited NATO summit in Wales to be held on 45 September 2014. A third area was the assistance and mediation of direct talks between Russia and Ukraine in an attempt to save what could be saved from the Berlin declaration of 2 July 2014.

In two of those areas, Berlin's efforts were as successful as possible under the given circumstances. This applies to the economic sanctions whose scope and nature had to be negotiated among the career diplomats representing their respective EU member states in Brussels. In a protracted and arduous negotiation process that in the second week of September 2014 stood on the brink of disruption, Berlin managed to overcome not only the resistance of France, where the cancellation of a one billion euro contract with Russia on the construction of a helicopter carrier in the shipyard of Saint-Nazaire met stiff resistance by the unions and President Hollande's own Socialist Party, but also to persuade a particularly stubborn Italian Prime Minister Renzi to give his consent to the new package of sanctions. Chancellor Merkel was equally successful in her efforts to strike a balance between the claims of Poland, Lithuania, Latvia and Estonia together with NATO Supreme Commander General Breedlove to deploy substantially more NATO ground forces in these countries and the German goal of not suspending NATO Russia links altogether and of preserving, at least formally, the NATO Russia Founding Act of 1997 (see above). In both domains further sanctions and bold but limited enhancement of NATO capacity in Poland and the Baltic States the German brokerage was skillful and determined.

Not surprisingly, things were different as far as the mediation between Russia and Ukraine was concerned. Russian support and barely concealed direct military action in Eastern Ukraine had, in the meantime, bolstered the position of the pro-Russian insurgents in Eastern Ukraine. In addition, President Putin called for some sort of 'statehood' for Eastern Ukraine. ${ }^{66}$ Putin and Ukrainian President Poroshenko met for their first direct talks (besides a very short meeting in Deauville, France, in early June) in Minsk on 26 August 2014. Their meeting remained inconclusive at first glance but a telephone conversation of the two presidents of 3 September 2014, finally paved the way to a truce deal between Ukraine and pro-Russian 'separatists' that was signed 5 September 2014.

The truce remained more than fragile, however. The UN Human Rights Monitoring Mission in Ukraine (HRMMU), in a report of 20 November 2014, stated that in the period between 6 September and 18 November 2014, 957 persons had been killed in the East of Ukraine and the 'the number of internally displaced people (IDPs) has also sharply increased from 275,489 as of 18 September to 466,829 on 19 November' due to 'the total breakdown of law and order and the emergence of parallel governance systems in the territories under the control of the [self-proclaimed] "Donetsk people's republic" and the [self-proclaimed] "Luhansk people's republic"' and 'the continuing presence of a large amount of sophisticated weaponry, as well as foreign fighters that include servicemen from the Russian Federation' which, according to the report, 'directly affects the human rights situation in the east of Ukraine'. 67

The German Federal Government made the Minsk agreement of 5 September 2014, the focal point of further diplomatic efforts and Chancellor Merkel emphasized the particular responsibility of Russia for its implementation. ${ }^{68}$ In a formal governmental statement (Regierungserklärung) before the Bundestag on 16 October 2014, she said that 'Russia has to make the decisive contribution to de-escalation [in East Ukraine]' and that full implementation of the Minsk agreement 'requires, among other things, the withdrawal of Russian weaponry, effective border control under OSCE auspices and municipal elections in East Ukraine according to Ukrainian law'. ${ }^{69}$

Those demands, according to all evidence, fell on deaf ears when Merkel met President Putin on 16 November 2014, at the G20 summit in Brisbane, Australia, in an atmosphere still shaped by the downing of $\mathrm{MH} 17$ that had claimed the lives of 38 Australian citizens and aggravated by the demonstrative deployment of a Russian flotilla in the international waters off the Australian coast. Merkel and Putin conferred for almost four hours. In a subsequent speech at the Lowy Institute for International Policy in Sydney, Merkel castigated 'forces, still existing in Europe, who refuse to honor the principles of mutual respect and peaceful conflict resolution ... which is what happened through the annexation of Crimea in violation of international law'. She also accused Russia of violating 
the territorial integrity and sovereignty of Ukraine thus putting into jeopardy the entire peaceful order of Europe, a development aggravated, Merkel said, through Russia's destabilizing influence in the Donetsk and Lugansk region in East Ukraine. ${ }^{70}$

These unmistakable statements notwithstanding, the German government was incapable of developing a coherent policy and communication strategy in the wake of the Minsk agreement of September 5, 2014. Foreign minister Steinmeier, in a newspaper interview of 16 November 2014, refrained from emphasizing Russia's obstruction of the agreement at all. Instead, he announced that no new EU sanctions against Russia were in the offing. ${ }^{71}$ When NATO Secretary General Jens Stoltenberg, on 18 November 2014, made public new evidence of intensified Russian military moves at the Russian Ukrainian border, including the deployment of heavy weaponry and 'very sophisticated air defense systems $s^{\prime 72}$, Steinmeier did not pick up the issue at a common appearance with his Russian counterpart Lavrov in Moscow the same day, followed by an unannounced reception by President Putin in the Kremlin. ${ }^{73}$ Instead, Vice Chancellor Gabriel, in a statement summarizing the results of a meeting of the supreme committee of the SPD of 24 November 2014, expressed concerns over intensified NATO presence in East European member states and drills 'close to the Russian border' that easily could lead to further escalation. ${ }^{74}$ The day before, Steinmeier had repeated that Ukraine should not join NATO. $^{75}$

Thus, Berlin sent mixed messages and exposed intragovernmental faultlines. While chancellor Merkel, at a press conference after the EU summit of 18 December 2014, kept emphasizing the conditionality of the sanctions against Russia and Russia's responsibility for the conditions to be met, ${ }^{76}$ Steinmeier, in an interview of 19 December 2014, expressed concerns that further sanctions could lead to uncontrolled economic deterioration in Russia. ${ }^{77}$ Indicative enough, the German foreign minister one more time refrained from pinpointing Russia's own discretionary leeway to alleviate the sanction regime and to avert the very economic consequences he was referring to. It is hard to determine if his omission was part of well-intended signaling or mere diplomatic blunder. At any rate, it necessarily weakened the leverage visà-vis Moscow as well as Germany's integrative capacity within the EU and, consequently, the auspices of the very diplomatic solution of the Ukrainian crisis the country is officially committed to.

\section{Conclusions: arduous learning or new 'German uncertainties'?}

The Russian aggression against Ukraine made obsolete a core concept of German foreign policy which was the 'partnership in modernization' with Russia. Moreover, it propelled Germany, a country that for decades had preferred to stay on the sideline in international conflict management, into a position of an indispensable crisis manager. Accordingly, German foreign policy had to adapt principled and causal beliefs espoused so far. That affected the notion of privileged relationships with Russia for the mutual political and economic benefit as a key element of a European peace and security architecture, however imperfect. German crisis management required an appropriate tactical disposition, mobilizing domestic support and acceptance for a more assertive policy vis-àvis Russia and crafting a common policy of the EU member states in cooperation with the US.

What one may preliminarily conclude is that German foreign policy did adapt its principled beliefs as far as the German Russian relationship is concerned and was successful in integrating EU and NATO over the crisis, but did not manage to adapt decisively causal beliefs at the tactical level. While German foreign policy makers, Chancellor Merkel and Foreign Minister Steinmeier in particular, displayed remarkable skill in organizing the political consensus within both EU and NATO, thus bridging the wide gap between the expectations of Poland and the Baltic States on the one hand and the reluctance of EU key states like France and Italy to implement fully fledged economic sanctions on Russia on the other, the mobilization of domestic support and acceptance was subject to ambiguity and internal frictions within the governing Grand Coalition in Berlin.

Capitalizing on his credibility as a true torchbearer of German Russian partnership, Steinmeier, on the one hand, was also effective in mobilizing acceptance for a new realism in German Russian relations. This affected primarily his own Social Democratic Party and German business circles with great expectations connected with the 'partnership in modernization'. On the other hand, Steinmeier still invested much hope in Russian willingness to achieve a stable political solution of the Ukrainian crisis and for the future of Ukraine in general. This led to tactical errors such as nonnegotiated concessions to Russia like the categorical rejection of future Ukrainian NATO membership and an unmistakable distance towards a determined implementation of the EU sanction plan of 6 March 2014. However, Steinmeier's excellent personal relationship with Polish Foreign Minister Sikorski was chiefly instrumental in mitigating the detrimental effects of Germany's reluctant position within NATO as far as the reinforcement and reassurance of NATO solidarity and protection of Poland and the Baltic States was concerned. There was also early consensus between Steinmeier and Merkel on what turned out to be a viable compromise agreed at the NATO Summit in Wales of early September 2014. It entailed the substantial reinforcement of NATO's deployment capacity and infrastructure in 
Eastern Europe but kept the NATO Russia Founding Act of 1997 at least formally intact.

Of pivotal importance in the long run is the fact that the Russian aggression against Ukraine galvanized the German efforts to redefine the country's role in NATO and to adjust both military spending and armament policy. In mid-October 2014, the Federal Government decided to increase military spending, to modernize German combat troops and to streamline its strategic armament policy. This, however, does not alter the fact that Germany continues to walk a tightrope between realism and false assumptions about Russia's willingness and ability to return at least to calculable rivalry as a prerequisite of minimal political stability in Eastern Europe and beyond. So far, the new disposition of Russian foreign policy, including collective self-deception and military aggression, amounts to an adventurous experiment which involves purposeful destabilization as a geopolitical tool. Next to transnational terrorism Russia's subversion of principles of calculable risk taking is likely to define the major external challenge to EU and NATO in the foreseeable future.

Germany will continue to play a crucial role in developing appropriate responses. It is, however, hard to predict whether arduous adaptation or renewed 'German uncertainties' will prevail. On the one hand, the governing Grand Coalition is committed to a double-tracked policy that combines shuttle diplomacy and intense dialogue with Russia with determined action on the basis of the echeloned sanction plan agreed upon by the European Council on 6 March 2014. On the other hand, the combined effect of century-old Russian German rival partnership, economic linkages and the legacy of peace and stability under the auspices of détente policy during the Cold War form a strong undercurrent shaping the interplay of domestic and foreign policy. In the absence of profound experience with sustainable crisis management in general and coercive diplomacy in particular, the main challenge is to reduce volatility in terms of strategic communication and actual decision making. To a large extent, the current federal government of Christian and Social Democrats managed to live up to that necessity. Faultlines do exist, however, and it cannot be taken for granted that Germany remains the forceful and reliable key player it has been so far in response to a new aggressive Russian foreign policy.

\section{Notes}

1. ARD Deutschlandtrend April 2014. By contrast, 45 per cent of respondents affirmed a statement according to which Germany, in the stand off between the west and Russia over Ukraine, should stand firm within the western alliance, while 35 per cent supported enhanced NATO engagement in Poland and the Bal tic States in the reduced form of 'air policing' (Luftraumuberwa chung).
2. Gerhard Schroder, German chancellor 1998 2005, rejected the idea of the EU serving as a mediator since the EU had sided with the Majdan movement and, therefore, could not act, according to Schroder, as a neutral mediator (spiegel online, 3 March 2014). Helmut Schmidt, the 96 year old ex chancellor and co editor of the weekly Die Zeit was quoted as saying he could 'certainly understand' Putin's action since, nota bene, there was no such thing as a Ukrainian nation (Die Zeit, 26 March 2014) a statement remarkably similar to what throughout centuries was German and Russian common sense as far as Poland and the Polish nation was concerned (cf. Snyder, 2011, p. 120: 'Ger man soldiers [before attacking Poland on 1 September 1939] had been instructed that Poland was not a real country, and that its army was not a real army', which led to countless war crimes under the pretext that Polish soldiers would not deserve the treatment of regular combatants).

3. 'CDU Vize Laschet beklagt, AntiPutin Populismus,' Die Welt, 18 March 2014; 'CSU und Linke vereint in der Ukraine Krise,' Die Welt, 4 May 2014; 'Sanktionen sind Eskalationen', Zeit online, 13 May 2014. Gauweiler who, on the occasion of a trip to Mos cow, had criticized the sanctions of the west against Russia as 'cowardly' and 'misdirected' (Suddeutsche Zeitung, 13 Septem ber 2014) intended to go to annexed Crimea in September 2014 in his capacity as chairman of the Bundestag sub committee on foreign cultural affairs, a trip that would have required permission of the Speaker of the Bundestag, Norbert Lammert, which was not given (Zeit online, 14 September 2014).

4. cf. 'Die Wirtschaft und die Ukraine Krise. Versuch einer Verein nahmung', Frankfurter Allgemeine Zeitung, 10 April 2014.

5. 'Platzeck fordert Anerkennng der Krim Annexion,' Zeit online, 18 November 2014.

6. 'Wieder Krieg in Europa? Nicht in unserem Namen!' [War again in Europe? Not in our name!], Die Zeit, 5 December 2014. Accompanying the article was a photo depicting US and Polish soldiers during a drill in Poland in May 2014 obviously meant as an illustration of the risk of war mentioned in the declara tion's headline. A countercritique of more than 100 scholars and experts appeared one week later in the same paper ('Friedenssicherung statt Expansionsbelohnung' [Safeguarding Peace in lieu of Premium on Expansion], Die Zeit, 11 December 2014).

7. This refers to a definition by Goldstein and Keohane (1993) according to which foreign policy makers act on the basis of principled assumptions on what is good, appropriate and right, assumptions that under usual circumstances are not subject to political discourse or debate. Causal beliefs, by contrast, are explicit or implicit assumptions on cause effect linkages at the operational level of foreign policy such as a belief in negotia tions and/or coercive diplomacy as an appropriate tool of crisis management.

8. While France, Germany and Poland had sent their foreign minis ters to Kiev, Russia was represented only by a government offi cial of secondary rank Vladimir Lukin an indicator of Russia's questionable commitment to the entire agreement.

9. UN, Office of the High Commissioner for Human Rights, 'Pro tracted conflict in eastern Ukraine continues to take heavy toll on civilians,' 8 October 2014.

10. In 2013, exports of goods and services represented 51 per cent of the German GDP (US 14 per cent, China 26 per cent, Japan 15 per cent, UK 31 per cent, France 27 per cent, Russia 28 per cent). Source: http://data.worldbank.org/indicator/NE.EXP.GNFS.ZS (Accessed 11 December 2014). 
11. 'Modernisierungspartnerschaft'. Deutsch russische Regierungs konsultationen in Jekaterinburg, Focus online, 14 July 2010. See also Stewart, 2011.

12. In 2013, Russian gas and oil supply accounted for 40 per cent (gas) and 34 per cent (oil) of related German imports. Reply by the Federal Government to the 'Kleine Anfrage' of the members of parliament Oliver Krischer, Kerstin Andreae, Dr Julia Verlinden, others and the faction BUNDNIS 90/DIE GRUNEN, Deutscher Bundestag, Drucksache 18/961. 17 April 2014, 'Position der Bun desregierung zu Energierohstoffimporten aus Russland', pp. 78.

13. Tweet by Carl Bildt, 'Ukraine government suddenly bows deeply to the Kremlin. Politics of brutal pressure evidently works.' https://twitter.com/carlbildt/status/403521513342898176.

14. Cf. Markus Wehner, 'Steinmeiers große Illusion,' Frankfurter Allgemeine Sonntagszeitung, 16 March 2014.

15. 'Germany's role in the world: Reflections on responsibility, norms and alliances'. Speech by Federal President Joachim Gauck at the opening of the Munich Security Conference on 31 January 2014 in Munich [online]. Available from: http://www.bundesprae sident.de/SharedDocs/Reden/DE/Joachim Gauck/Reden/2014/01/ 140131 Muenchner Sicherheitskonferenz.html. Speech by Foreign Minister Frank Walter Steinmeier at the 50th Munich Security Con ference, 1 February 2014 [online]. Available from: http://www. auswaertiges amt.de/EN/Infoservice/Presse/Reden/2014/140201 BM M\%C3\%BCSiKo.html. Speech by the Federal Minister of Defense, Dr Ursula von der Leyen, on the Occasion of the 50th Munich Security Conference Munich, 31 January 2014[online]. Available from: https://www.securityconference.de/fileadmin/MSC / 2014/Reden/2014 0131 Rede BMin von der Leyen MSC 2014. pdf. All URLs accessed 12 December 2014.

16. Speech by Foreign Minister Frank Walter Steinmeier on the occa sion of his inauguration, 17 December 2013 [online]. Available from: http://www.auswaertiges amt.de/DE/Infoservice/Presse/Reden/ 2013/131217 BM Antrittsrede.html [Accessed 11 December 2014].

17. russland.RU, 14 February 2014. Cf. also 'Steinmeier in Russland. Richtungsweisende Visite in Moskau', Neue Zurcher Zeitung, 14 February 2014.

18. In an interview with Deutschlandfunk, the nationwide public radio, of 24 February 2014, Gernot Erler, the Federal Government's 'Coordinator for Intersocietal Cooperation with Russia, Central Asia and the Eastern Partnership Countries' insisted that Lukin had signed the Kiev agreement of 21 February which, according to Erler, should be appreciated (Available from: http://www.deu tschlandfunk.de/ukraine erler timoschenko ist keine ikone.694.de. html?dram:article id=278305 [Accessed 11 December 2014]) while Lukin himself, in a Russian TV interview of 22 February, had admitted that he had not signed the agreement because, as he said, it had been unclear to whom it would be addressed and who would be in charge of implementing it (according to Fried rich Schmidt, 'Keine Reaktion, Brachialrhetorik oder offene Einmis chung. Moskaus Optionen in der Ukraine,' Frankfurter Allgemeine Zeitung, 24 February 2014).

19. Deutschlandfunk, 2 March 2014; TV interview Frank Walter Stein meier, ARD, 2 March 2014 ('Steinmeier will Russland in der G8 Gruppe halten' [Steinmeier wants to keep Russia in G8 group]).

20. Common Declaration of the Foreign Ministers of the Weimar Tri angle of 30 March 2014.

21. Foreign Minister Frank Walter Steinmeier, speech before the 'East Forum Berlin', a newly founded center for German East European economic cooperation, 9 April 2014.

22. cf. Markus Wehner, 'Steinmeiers große Illusion', Frankfurter All gemeine Sonntagszeitung, 16 March 2014. 'After the outbreak of the Crimea crisis he [Steinmeier] had to move with almost supersonic speed in order to stay up to date.'

23. Reflected in the coverage of Steinmeier's speech before the 'East Forum Berlin' by Majid Sattar, correspondent of the Frank furter Allgemeine Zeitung with noted ties to sources in the Auswartiges Amt (Majid Sattar, 'Die Wirtschaft und die Ukraine Krise. Versuch einer Vereinnahmung,' Frankfurter Allgemeine Zeitung, 4 April 2014).

24. Wolfgang Ischinger, former State Secretary (Deputy Foreign Min ister) of the German Foreign Office, on the popular Gunther Jauch talk show, 2 March 2014; Interview Gernot Erler, 'Coordi nator for Intersocietal Cooperation with Russia, Central Asia and the Eastern Partnership Countries' of the Federal Government, Deutschlandfunk, 5 March 2014.

25. European Council, Statement of the Heads of State or Government on Ukraine, Brussels, 6 March 2014 [online]. Available from: http:// www.consilium.europa.eu/uedocs/cms data/docs/pressdata/en/ec/ 141372.pdf [Accessed 11 December 2014].

26. 'G20 warnen: Ukraine Krise ist Gefahr fur die Weltwirtschaft', Focus online, 11 April 2014.

27. The headline of the online edition of Tagesschau, the news flag ship of Germany's number one TV channel, read 'Steinmeier warnt vor neuen Sanktionen' [Steinmeier warns against new sanctions].

28. Deutschlandfunk, 5 June 2014.

29. Especially prone to such distortion of cause effect relationship was once again the Federal Government's 'Coordinator for Intersocietal Cooperation with Russia, Central Asia and the Eastern Partnership Countries', Gernot Erler, who in a series of interviews, despite the unanimous EU decision of early March 2014, declared sanctions against Russia inappropriate and incompatible with a 'diplomatic outcome' of the crisis (spiegel online, 4 April 2014) and called for a cessation of what he called a Ukrainian 'military operation' in defense of Ukrainian territory against the Russian controlled insur gency in Eastern Ukraine (Neue Osnabrucker Zeitung, 7 May 2014), a statement he repeated even after the downing of the Malaysian airplane MH17 over insurgent controlled Ukrainian territory (Neue Osnabrucker Zeitung, 2 August 2014).

30. cf. Nikolas Busse, 'Der verborgene Teil deutscher Außenpolitik,' Frankfurter Allgemeine Zeitung, 28 March 2014; Matthew Kar nitschnig, 'Berlin Takes Softer Tack With Putin,' The Wall Street Journal, 8 April 2014.

31. Burns, R. N., Wilson, D. M., Lightfoot, J. (2012) 'Anchoring the Alliance,' Washington D.C.: Atlantic Council, p. 5.

32. 'von der Leyen: NATO Prasenz an den Außengrenzen jetzt wich tig', Zeit online, 23 March 2014.

33. 'Gabriel kritisiert von der Leyen fur Außerungen zu NATO Prasenz,' Frankfurter Allgemeine Zeitung, 25 March 2014.

34. 'Gabriel kritisiert von der Leyen fur Außerungen zu NATO Prasenz,' Frankfurter Allgemeine Zeitung, 25 March 2014.

35. Cf. for the related basics in international relations theory Tho mas Schelling (1960) The Strategy of Conflict, Cambridge, MA: Harvard University Press, and Robert Axelrod (2006) The Evolu tion of Cooperation, revised edition. New York, NY: Basic Books.

36. Nikolas Busse, 'Der verborgene Teil deutscher Außenpolitik,' Frankfurter Allgemeine Zeitung, 28 March 2014; 'Berlin verwahrt sich gegen Zweifel in der NATO,' Frankfurter Allgemeine Zeitung, 29 March 2014.

37. Spiegel online, 30 March 2014.

38. A recurrent pattern of German comments on Poland's, Lithua nia's, Latvia's and Estonia's requests for more substantial military support by NATO was, indicatively enough, that those states were allegedly not threatened by Russia. The implicit arrogance 
of such statements, especially in the light of the history of Ger man Russian accords at the expense of those very states, escaped both their authors and the attention of a broader media coverage. Cf. Interview Walther Stutzle, former State Secretary (Deputy Minister) to the Federal Ministry of Defence, Deutsch landfunk, 1 April 2014 ('Es gibt keine Bedrohung fur die baltis chen Staaten' [No threat is exerted on the Baltic states]), or Interview Lothar de Maizière, Frankfurter Allgemeine Zeitung, 21 November 2014 ('Heute aber sehe ich keine Gefahr fur Polen.' [Today, I do not see any danger for Poland']). Both Stutzle and de Maizière were among the signatories of the declaration 'Wie der Krieg in Europa? Nicht in unserem Namen!' [War again in Europe? Not in our name!], Die Zeit, 5 December 2014 (see above, note 6).

39. Deutschlandfunk, 10 May 2014.

40. spiegel online/Deutsche Presse Agentur, 30 March 2014.

41. 'Steinmeier lehnt NATO Beitritt der Ukraine ab,' spiegel online, 1 April 2014.

42. 'Steinmeier gegen NATO Mitgliedschaft der Ukraine,' Frankfurter All gemeine Zeitung, 11 April 2014; 'Steinmeier lehnt NATO Mitglieds chaft der Ukraine ab,' Suddeutsche Zeitung, 24 November 24, 2014.

43. 'NATO leaders take decisions to ensure robust Alliance,' NATO, press release, 5 September 2014.

44. French Foreign Minister Laurent Fabius had, for instance, left the Majdan negotiations in Kiev of 2021 February 2014, prematurely.

45. Deutschlandfunk, 2 March 2014; 'Steinmeier will schnell OSZE Beobachter entsenden,' Zeit online, 19 March 2014.

46. 'Merkel wirft Russland Volkerrechtsbruch vor. Vorwurf mit Ange bot zum Dialog', Tagesschau, 2 March 2014.

47. In the Gunther Jauch show of Germany's first TV Channel ARD of 2 March 2014, Ischinger said, 'sanctions is the last thing we are in need of'. At that time, Ischinger also rejected the idea of excluding Russia from the upcoming G8 summit of June 2014, a step that was announced by the US government, referring to the consent of the remaining G7 states, including Germany, the very same evening, US East Coast Time. He also, on the same occasion, warned against repeating the 'mistake' committed, in his judgment, after the Russian invasion of Georgia in 2008 when the NATO Russia Council was temporarily suspended. Especially in times of crisis, Ischinger said, talking to each other was the order of the day.

48. Deutschlandfunk, 5 May 2014

49. Joint statement from G7 leaders about the ongoing situation in Ukraine and additional sanctions on Russia, 26 May 2014.

50. 'Steinmeier warnt vor Sanktionen gegen Russland', Suddeut sche.de, 20 April 2014.

51. The New York Times, 3 May 2014. Russia's special envoy who brokered the release of the OSCE hostages happened to be the very same Vladimir Lukin who had participated in the negotia tions that led to the Majdan agreement of 21 February 2014. This personal acquaintance might at least partly explain the overly warm appreciation of the German Foreign Minister.

52. Deutsche Presse Agentur, 2 May 2014.

53. Deutschlandfunk, 19 May 2014.

54. 'Ukraine implements cease fire in restive east', CNN online, 20 June 2014

55. European Council, Brussels, 27 June 2014, 'European Council conclusions Ukraine'.

56. European Council, Brussels, 27 June 2014, 'European Council conclusions Ukraine'.

57. Interview Norbert Rottgen, Deutschlandfunk, 1 July 2014.

58. Deutschlandfunk, 29 June 2014.

59. Press Release, Elysée Palace, 29 June 2014.
60. German Federal Foreign Office, Press Release, 'Joint Declaration by the Foreign Ministers of Ukraine, Russia, France and Ger many', 2 July 2014.

61. Tagesschau, 2 July 2014.

62. 'Gabriel: Russland Sanktionen werden schnell wirken', Reuters Deutschland, 30 July 2014.

63. 'Steinmeier: Nur mit Moskau', Frankfurter Allgemeine Zeitung, 3 August 2014.

64. Deutschlandfunk, 16 August 2014.

65. Markische Allgemeine Zeitung, 31 August 2014.

66. 'Putin will Gesprache uber Staatlichkeit der Sudostukraine', tag esschau.de, 31 August 2014.

67. UN Human Rights Monitoring Mission in Ukraine, 'Serious human rights violations persist in eastern Ukraine despite tenu ous ceasefire,' Geneva, 20 November 2014. See also Cathrin Kahlweit: 'Niemandsland,' Suddeutsche Zeitung, 16 December 2014, on the desperate living conditions and serious human rights deterioration in the self proclaimed Luhansk and Donetsk 'Peoples' Republics' in East Ukraine.

68. Press release: Bundeskanzlerin Merkel telefoniert mit Prasident Putin [Federal Chancellor Merkel telephones President Putin], Presse und Informationsamt der Bundesregierung, 1 October 2014; Federal Chancellor Merkel, Policy Statement before the Bundestag, 16 October 2014.

69. Federal Chancellor Merkel, Policy Statement before the Bundes tag, 16 October 2014 [online]. Available from: http://www. bundeskanzlerin.de/Content/DE/Regierungserklaerung/2014/ 20141016 bt merkel.html [Accessed 12 December 2014].

70. Rede von Bundeskanzlerin Merkel am Lowy Institut fur Interna tionale Politik am 17. November 2014 (author's translation) [online]. Available from: http://www.bundeskanzlerin.de/Content/ DE/Rede/2014/11/2014 1117 merkel lowy institut.html (Accessed 12 December 2014).

71. Interview Steinmeier, Welt am Sonntag, 16 November 2014. Steinmeier reiterated this particular statement at the EU Foreign Ministers conference in Brussels on 17 November 2014; cf. Deu tschlandfunk, 17 November 2014.

72. 'NATO meldet Verstarkung russischer Truppen an der Grenze zur Ukraine', Deutschlandfunk, 18 November 2014.

73. 'Steinmeier zu Vermittlungsversuch in Moskau eingetroffen,' welt online, 18 November 2014. Steinmeier did say, however, that his talks with Lavrov and Putin had revealed 'serious differ ences' in the respective assessment of the events of the previ ous months. Cf. 'Steinmeier: Gravierende Differenzen mit Russland,' Deutschlandfunk, 18 November 2014.

74. 'SPD Chef zur Russland Politik: Gabriel warnt vor Eskalation', Tag esschau online, 24 November 2014.

75. 'Steinmeier lehnt NATO Mitgliedschaft der Ukraine ab', Suddeut sche Zeitung, 24 November 2014.

76. 'Die Sanktionen sind aus bestimmten Grunden verhangt wor den, und sie konnen nur durch den Wegfall dieser Grunde auf gehoben werden.' [The sanctions have been imposed by certain reasons and they only can be lifted in case those reasons disap pear.] welt online, 19 December 2014.

77. 'Außenminister contra EU: Steinmeier warnt vor scharferen Russ land Sanktionen', spiegel online, 19 December 2014.

\section{References}

Ash, T. G. (1993) In Europe's Name. Germany and the Divided Continent. New York, NY: Random House.

Ash, T. G. (1994) 'Germany's Choice', Foreign Affairs, 73, pp. 6581. 
Axelrod, R. (2006) The Evolution of Cooperation. Revised edition. New York, NY: Basic Books.

Beck, M. (2014) 'Die Ukraine Prufstein fur Europa', Frankfurter Allgemeine Zeitung, 11 October 2014.

Bulmer, S. (2014) 'Germany and the euro zone crisis: between hegemony and domestic politics', West European Politics, 36, pp. 12441263.

Burns, R. N., Wilson, D. M. and Lightfoot, J. (2012) Anchoring the Alliance. Atlantic Council: Washington D.C.

Paterson, W. E. (2011) 'The Reluctant Hegemon? Germany Moves Centre Stage in the EU', Journal of Common Market Studies, 49, pp. 5776.

Calleo, D. (1978) The German Problem Reconsidered. Germany and the World Order, 1870 to the Present. Cambridge: Cambridge University Press.

Goldstein, J. and Keohane, R. O. (1993) 'Ideas and Foreign Policy. An Analytical Framework,' in J. Goldstein and R. O. Keohane (eds) Ideas and Foreign Policy. Beliefs, Institutions, and Political Change. Ithaca, NY: Cornell University Press, pp. 330.

James, H. (2012) Making the European Monetary Union. Washington, DC: Bank of International Settlements, pp. 128.

Jarausch, K. H. (ed.) (2013) Uniting Germany: Debating Processes and Prospects. New York, NY: Berghahn.

Jervis, R. (1976) Perceptions and Misperceptions in International Politics. Princeton, NJ: Princeton University Press.

Maull, H. W. (1992) 'Zivilmacht Bundesrepublik Deutschland', Europa Archiv, 47 (10), pp. 269278.

Mazzucelli, C. (1995) 'Germany at Maastricht: Diplomacy and Domestic Politics', in A. B. Shingleton, M. J. Gibson and K. S. Mack (eds.) Dimensions of German Unification. Boulder, CO: Westview Press.

Miner, S. M. (1994) 'His Master's Voice: Viacheslav Mikhailovich Molotov as Stalin's Foreign Commissar', in A. C. Gordon and F. Loewenheim (eds) The Diplomats, 1939 1979. Princeton, NJ: Princeton University Press, pp. 65100.

Putnam, R. D. (1988) 'Diplomacy and Domestic Politics: The Logic of Two Level Games,' International Organization, 42, pp. 427460.
Schelling, T. (1960) The Strategy of Conflict. Cambridge, MA: Harvard University Press.

Seibel, W. (1992) 'Necessary Illusions. The Transformation of Governance Structures in the New Germany', Tocqueville Review, 13, pp. 178197.

Snyder, T. (2011) Bloodlands. Europe between Hitler and Stalin. New York, NY: Basic Books.

Stewart, S. (2011) Die deutsch russische Modernisierungspartnerschaft: Skepsis angebracht. Stiftung Wissenschaft und Politik (SWP), Series 'Kurz gesagt', 27 July .

Vinocur, J. (2014) 'The Russia lobby in Germany: Berlin's foreign policy leadership boils down to "let's talk this over" and "maybe we can do nothing",' The Wall Street Journal, 31 March 2014.

Watt, D. C. (1989) How War Came. The Immediate Origins of the Second World War, 1938 1939. New York, NY: Pantheon Books.

\section{Author Information}

Wolfgang Seibel is Professor of Politics and Public Administration at the University of Konstanz, Germany, and an Adjunct Professor of Public Administration at the Hertie School of Governance, Berlin. He studied Political Science and Administrative Science at University of Marburg and at the German Graduate School of Administrative Sci ence, Speyer. He obtained his PhD at the University of Kassel (1982) where he also completed his Habilitation in Political Science (1988). $\mathrm{He}$ is a member of the Heidelberg Academy of Science and a mem ber of the Academic Committee of the Martin Buber Society of Fel lows in the Humanities and Social Sciences at Hebrew University, Jerusalem. He held guest professorships at the University of Califor nia at Berkeley and Stanford University and fellowships at the Insti tute for Advanced Study, Princeton, and the Wissenschaftskolleg, Berlin. Seibel's research focuses on the theory of public administra tion and international bureaucracies in various forms ranging from occupation regimes during the Second World War and its impact on the Holocaust to humanitarian intervention and complex UN peace keeping missions and their linkages to foreign policy. 